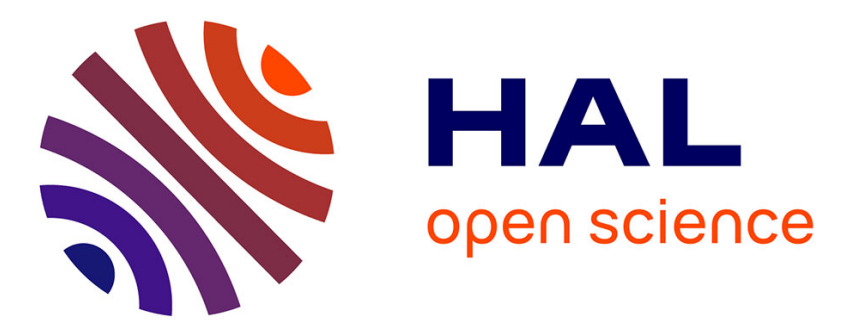

\title{
VAPOUR PRESSURE MEASUREMENTS ON AMORPHOUS Ge16Te84 ALLOY BY KNUDSEN CELL MASS SPECTROMETRY
}

Claire Bergman, R. Chastel

\section{- To cite this version:}

Claire Bergman, R. Chastel. VAPOUR PRESSURE MEASUREMENTS ON AMORPHOUS Ge16Te84 ALLOY BY KNUDSEN CELL MASS SPECTROMETRY. Journal de Physique Colloques, 1982, 43 (C9), pp.C9-199-C9-203. 10.1051/jphyscol:1982935 . jpa-00222464

\section{HAL Id: jpa-00222464 https://hal.science/jpa-00222464}

Submitted on 1 Jan 1982

HAL is a multi-disciplinary open access archive for the deposit and dissemination of scientific research documents, whether they are published or not. The documents may come from teaching and research institutions in France or abroad, or from public or private research centers.
L'archive ouverte pluridisciplinaire HAL, est destinée au dépôt et à la diffusion de documents scientifiques de niveau recherche, publiés ou non, émanant des établissements d'enseignement et de recherche français ou étrangers, des laboratoires publics ou privés. 
JOURNAL DE PHYSIQUE

Colzoque C9, supplément au n $n^{0}$, Tome 43, décembre 1982

page C9-199

\section{VAPOUR PRESSURE MEASUREMENTS ON AMORPHOUS Ge ${ }_{16}$ Te $_{84}$ ALLOY BY KNUDSEN CELL NASS SPECTROMETRY}

C. Bergman and R. Chaste1

Centre de Thermodynamique et de Microcalomimétrie du C.N.R.S. 26, mie du 141ème R.I.A., 13003 Marseizle, France

Résumē. - La méthode d'effusion de Knudsen couplēe avec un spectromètre de masse est une mëthode souvent utilisẻe en métallurgie pour l'étude des équilibres chiniques dans les systèmes hëtërogènes.

Le but de ce travail est la mesure de la pression de vapeur du tellure au-dessus d'alliages amorphes Ge16Te84, préparés par trempe du liquide. Les mesures effectuêes de 370 à $650 \mathrm{~K}$ permettent de suivre la pression en équilibre avec l'état amorphe $(T<\mathrm{Tg}=410)$, $T^{\prime}$ 'état surfondu $\left(\mathrm{Tg}<\mathrm{T}<\mathrm{T}_{\mathrm{X}}\right)$ et $\mathrm{T}^{\prime}$ 'état cristal1in $\left(T>T_{X}=500\right)$.

$A T / K=400<\mathrm{Tg}$, la pression de vapeur du tellure au-dessus de I! amorphe est beaucoup plus élevée qu'au-dessus de l'échantillon cristallin de mëme composition.

Abstract. - The Knudsen effusion method coupled with a mass spectrometer is a weTT-known method often employed in metallurgy to study the chemical equilibria in heterogeneous systems.

The purpose of this work is to perform measurements of the vapour pressure of tellurium on $\mathrm{Ge}_{16} \mathrm{Te}_{84}$ amorphous alloys, obtained by liquid quenching. Experiments were performed in the temperature range $370<\mathrm{T} / \mathrm{K}<650$ yielding the variation of the vapour pressure on the amorphous alloys $(T<\mathrm{Tg}=410)$, on the supercooled alloys ( $\mathrm{Tg}<\mathrm{T}<\mathrm{T}_{\mathrm{X}}$ ) as well as on the cristalline ones $\left(T>T_{X}=500\right)$.

At $T / K=400<\mathrm{Tg}$, the vapour pressure of tellurium is much higher than over the cristalline sample of the same composition

\section{Introduction.}

The application of the semiconducting amorphous materials and especially chalcogenides glasses for switching and memory has been discovered about fifteen years ago $(1,2)$. Since that, some studies related to their thermal stability have been reported in the literature ; in particular, for the germanium-tellurium system, a study has been undertaken in order to identify the effects of composition and method of preparation on glass transition and heat capacity measurements have been performed on both liquid and glassy alloys (3) ; on the other hand, densities, viscosities and mechanical properties have been measured for the GexTe1-x alloys and a tentative interpretation has pointed out the existence of a three-fold coordination for the tellurium atoms engaged in the amorphous alloys (4).

The aim of this work is related to the possibility of knowing the relative stability of 211 the present phases as was mentionned by Shimoji as an important point (5). This leads to the hypothetical diagram introduced by Köster $(6,7)$ in which the reactions occuring during the transition amorphous-crystalline phases are given in terms of the free energies versus composition for the different phases. The question arises if thermodynamics can apply to amorphous materials; the condition is that the macroscopic state of a given phase for a given chemical composition has to be determined by thermodynamic variables such as $P$ and $T$. Therefore the relaxation-time has to be of different order compared to the experimental time-scale and this is not the case of the intermediate transition region where properties are time dependent. However this condition is fulfilled both for the metastable solid glass and supercooled liquid. 
The measurements of vapour pressure of tellurium in equilibrium with amorphous $\mathrm{Ge}_{16}$ Te84 alloys are carried out by the Knudsen cell mass spectrometry technique, which has been proved to be a powerful tool for thermodynamic measurements (8). Until now, we applied this method to liquid metaliic systems, two of wich were tellurium based (9) and recently to vitreous oxides melts (10).

\section{Experimenta1.}

\section{Technique.}

The present work is carried out with a Varian Mat-CH5 mass spectrometer, the special feature of which has already been described (11). The spectrometer is provided with a molecular beam analyzer in order to differentiate the part issuing from the cell and the background. A view of the furnace in which the samples are evaporated is presented in Fig. 1. The Knudsen cell is made of vitreous carbon (Le Carbone-Lorraine, CV 2500). The cell is covered with a graphite disc provided with a hole $1.5 \mathrm{~mm}$ in diameter and placed in a dense graphite container (Le Carbone Lorraine, 5890 PT), to

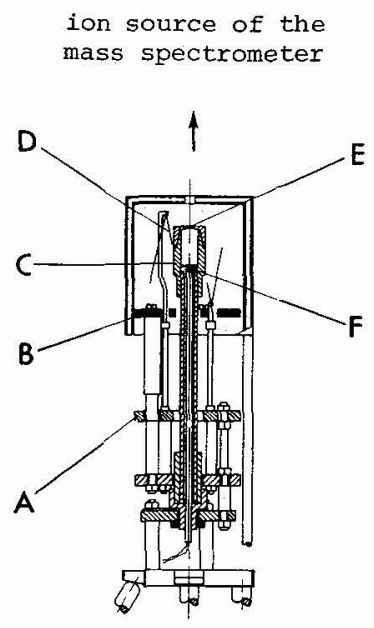

Fig. 1 : Knudsen-cell equipment coupled with the mass spectrometer :

A : isolated mechanical support -

$B$ : condensation plate -

$C$ : Knudsen cel1 -

$D$ : heating filaments -

E : effusion hole -

$\mathrm{F}: \mathrm{Pt} / \mathrm{Pt}-\mathrm{Rh}$ thermocouple.

avoid a temperature gradient. The Knudsen cell is heated by radiation and temperature increased by steps. The temperature is measured with a Pt-Pt Rh $10 \%$ thermocouple 10cated at the bottom of the container and calibrated at the eutectic level $(T=650 \mathrm{~K})$. According to our previous studies (9), ${ }^{130} \mathrm{I}_{\mathrm{Te}}$ and ${ }^{256} \mathrm{I}_{\mathrm{T}_{\mathrm{e}}}$ are monitored with $14 \mathrm{eV}$ electron energy. According to the phase diagram, the apparatus is directly calibrated by measuring the vapour pressure of pure tellurium in equilibrium with solid cristalline sample, during the experiment and compared to the literature values (12).

\section{Synthesis of amorphous materials.}

The alloys are synthetized from pure elements melted in suited proportions corresponding to the eutectic composition, Ge16 $\mathrm{Te}_{84}$, the value of which was previously checked by DTA. Each silica tube is filled with about $400 \mathrm{mg}$. The alloys are maintained $30 \mathrm{mn}$ at $1173 \mathrm{~K}$ and then a week at $873 \mathrm{~K}$. The tubes are then quenched in salt water, and then we obtain bulk amorphous $\mathrm{Ge}_{16} \mathrm{Te}_{84}$ cylindrical samples. X-Ray analys is were carried out to check the non crystaline structure of the samples. 
3. Results and discussion.

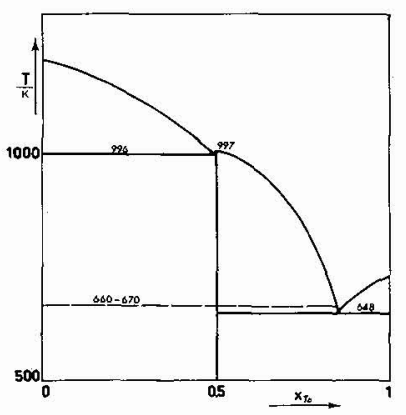

Fig. 2 : Phase diagram of germanium-tellurium system
Fig. 2 shows the phase diagram of the germaniumtellurium system reported in (13). It is quite simple with a single GeTe compound. Recent stu= dies referred in (13) indicate various transitions occuring in solid solutions around the compound.

The molar fraction of the investigated amorphous sample corresponds to the eutectic and its vitreous transition temperature is located at $T=409 \mathrm{~K}$; according to (3), the highest value for $\mathrm{Tg}$ with respect to composition is observed for $\mathrm{x}_{\mathrm{Te}}=0.67$. Experiments are performed in the temperature range $370<T / K<650$,

A mass spectrum is presented in Fig. 3. We can see the variation with temperature of the ionic intensity ${ }^{256} \mathrm{I}\left(\mathrm{Te}_{2}\right)$ in the vitreous transition range, quite vanishing at $\mathrm{Tg}$; the important variation occuring at the last temperature step is related to the thermal effect released by the sample when the cristallization arises.

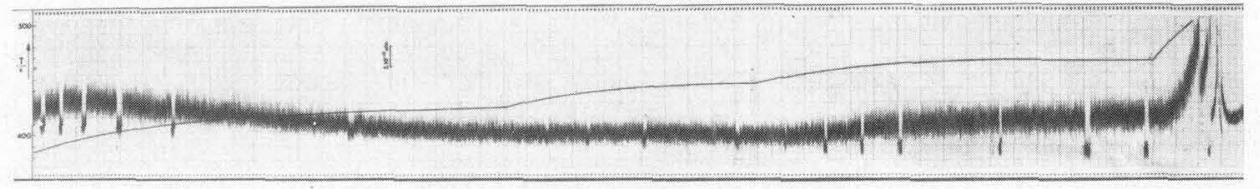

Fig. 3 : Mass spectrum of the intensity of ${ }^{256}{ }_{I}$ ( $\left.\mathrm{Te}_{2}\right)$ in the vitreous transition and cristalization ranges obtained with a Knudsen cell initially filled with amorphous $\mathrm{Ge}_{16} \mathrm{Te}_{84}$, additional scale indicates the simultaneous temperature variation.

The breaks in the spectrum are due to the beam analyzer described above and allow quantitative measurements.

The partial vapour pressure $P_{i}$ in the knudsen cell and the corresponding ionic intensity $\mathrm{I}_{\mathbf{i}}$ are related by

$$
P_{i} S_{i}=I_{i}^{\top}
$$

$S_{i}$, being a calibration constant.

Thus, the values of $\mathrm{Ln}\left|\mathrm{I}_{\mathrm{Te}_{2}} \mathrm{~T}\right|$ are platted on $\mathrm{Fig} .4$ versus the reciprocal temperature for a typical run, starting with an amorphous material, which undergoes heating and cooling cycles; the second heating cycle is performed for calibrating the apparatus; the following features can be observed.

- the vapour pressure over amorphous GeTe is much higher than over the cristaltine one $\frac{\mathrm{ITe}_{2}(\mathrm{am})}{\mathrm{ITe}_{2}(\mathrm{cr})}=100$. According to (12), the vapour pressure of pure cristalline tellurium at $\mathrm{Tg}$ is $7.10^{-14} \mathrm{~atm}$.

- at $\mathrm{Tg}$, the vitreous transition occurs, characterized by a change in the slope of the curve; with increasing temperature, the temperature dependence of the vapour pressure corresponds to the extrapolated values of the melts.

- at $T_{X}$, the break in the curve indicates the cristallization and then the vapour pressure follows the variation of cristalline sample, which is observed as well as the temperature is decreased. 


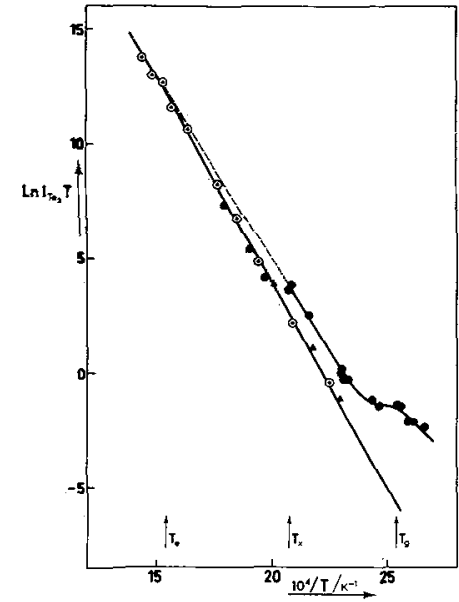

Fig. 4 : Variation of the Togarithm of the tellurium ionic intensity multiplied by temperature,

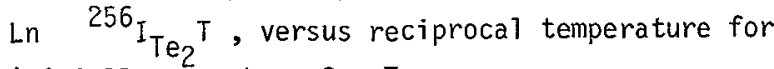
initially amorphous $\mathrm{Ge}_{16} \mathrm{Te}_{84}$.

- : by heating -

A : by cooling -

$\odot$ : by heating a second time.

- the measured heat of sublimation is $\Delta \mathrm{H}_{\mathrm{sub}}=78 \mathrm{~kJ} \mathrm{~mol}^{-1}$ to compare to $82 \mathrm{~kJ} \mathrm{~mol}^{-1}$ (12).

Another runs have been carried out with samples with the same composition, undergoing the same temperature cycles and yielding the same conclusions.

As far as we know, these data cannot be compared to literature ones; however, Gutzow has reported schematic curves of the temperature dependence of the vapour pressure (14) and calculated the same curve for glycerin from the values given by Simon (15). The same behaviour is observed with an even more important value for the vapour pressure ratio $\left(10^{4}\right)$.

The density measurements of amorphous GeTe alloys $\left(\mathrm{x}_{\mathrm{Te}}=0.80 ; 0.82 ; 0.84\right)$ reported by Schneider (4) yield to values which are $10 \%$ smaller than those of cristalline samples of same composition; this is in agreement with the higher vapour pressure observed over amorphous samples.

In conclusion, mass spectrometric results of the vapour pressure of tellurium in the vitreous transition and cristallization ranges show the temperature dependence of this property over cristalline, supercooled and amorphous samples ; the vapour pressure is very sensitive to the structure of the condensed phase in equilibrium. In order to gain an overall picture of the stability of these various phases, measurements over pure amorphous tellurium have to be performed. The free energies of liquid alloys have been carried out by electrochemical method (16) in the eutectic concentration range and it would be interesting to compare the entire set of data.

Acknowledgments. - We are indebted to Mrs Baron and Prof. C. Petot for the preparation of liquid quenched amorphous materials at the "laboratoire P.M.T.M., Universite Paris-Nord, France".

\section{References.}

1. OVSHINSKY S.R., Phys. Rev. Letters 21 (1968) 1450.

2. NEALE R.G., NELSON D.C. and MOORE G.E., Electronics 43 (1970) 56.

3. DE NEUFVILLE J.P., J. Non Cryst. Solids 8-10 (1972) $\overline{85}$.

4. SCHNEIDER M., Thèse CNAM (1978), Paris, France.

5. SHIMOJI M., J. Physique 41 (1980) 8, C8-547.

6. KOSTER U., Adv. CoTloid Interface Sci. 10 (1979) 129.

7. KOSTER U. and WEISS P., J. Non-Cryst. Solids, 17 (1975) 359.

8. CHATILLON C., PATTORET A. and DROWART J., High Temp. High Pres. 7 (1975) 119

9. SAID H., CHASTEL, R., BERGMAN C. and CASTANET R., Z. Metal 7 kunde 72 (1981) $5,360$.

10. ROGEZ J., CHASTEL R., BERGMAN C., BROUSSE C., CASTANET R. and MATHIEU J.C., BuT1. Minera1. (1982) to be published. 
11. BERGMAN C., CHASTEL R., GILBERT M. and CASTANET R., High Temp. High Pres. 10 (1978) 581.

12. HULTGREN R., DESAI P.D., HAWKINS D.T., GLEISER M., KELLEY K.K. and WAGMAN D.D., "Selected values of the thermodynamic properties of the elements" Am. Soc. Met., Meta1s Park, Ohio, USA, 1973.

13. MOFFATT W.G., "Binary phase diagrams handbook", General Electric, Schenectady, N.Y., 1976.

14. GUTZOW I., Z. Physik Chem. 81 (1972) 195.

15. SIMON F., Physica 4 (1937) 1089.

16. RAKOTOMAVO J., Thēse d'Etat, 1982 , Paris, France. 